ISSN 1678-3921

Journal homepage: www.embrapa.br/pab

For manuscript submission and journal contents, access: www.scielo.br/pab
Yoná Serpa Mascarenhas ${ }^{(1)}$ (iD, Mellissa Ananias Soler da Silva ${ }^{(2 \bowtie)}$ (iD, Vládia Correchel(3) (D), Alberto Baêta dos Santos ${ }^{(2)}$ (D), Márcia Thaís de Melo Carvalho(2) (DD, Beáta Emöke Madari(2) (D), Alexandre Siqueira Coelho( ${ }^{(3)}$ (iD, Gustavo Melo de Oliveira Gonçalves ${ }^{(3)}$ and Pedro Henrique Pereira Caetano(3)

(1) Instituto Federal do Piauí, Departamento de Agricultura e Pecuária, Campus Oeiras, Rua Projetada, s/no, CEP 64500-000 Oeiras, PI, Brazil.

E-mail: yona.mascarenhas@ifpi.edu.br

(2) Embrapa Arroz e Feijão, GO-462, Km 12, Zona Rural, CEP 75375-000 Santo Antônio de Goiás, GO, Brazil.

E-mail: mellissa.soler@embrapa.br, alberto.baeta@embrapa.br, marcia.carvalho@embrapa.br, beata.madari@embrapa.br

(3) Universidade Federal de Goiás, Escola de Agronomia, Campus Samambaia, Rodovia Goiânia-Nova Veneza, Km 0 , CEP 74690-900 Goiânia, GO, Brazil. E-mail: vladiacorrechel@hotmail.com, alexandre_coelho@ufg.br, gustavo@agricolaceres.com.br, pedrocaetano.agro@gmail.com

$\bowtie$ Corresponding author

Received

May 16, 2019

Accepted

September 30, 2020

How to cite

MASCARENHAS, Y.S.; SILVA, M.A.S. da; CORRECHEL, V.; SANTOS, A.B. dos; CARVALHO, M.T. de M.; MADARI, B.E.; COELHO, A.S.; GONÇALVES, G.M. de O.; CAETANO, P.H.P. Emission of nitrous oxide in flooded rice cultivation in Brazil. Pesquisa Agropecuária Brasileira, v.55, e01497, 2020. DOI: https://doi.org/10.1590/S1678-3921. pab2020.v55.01497.

\section{Emission of nitrous oxide in flooded rice cultivation in tropical area of Brazil}

\begin{abstract}
The objective of this work was to evaluate the effects of nitrogen fertilizers on the $\mathrm{N}$ dynamics and grain yield in flooded rice (Oryza sativa) cultivation in Brazilian tropical wetland. The experiment was carried out in a randomized complete block design with six treatments, as follows: common and protected urea; topdressing application of $\mathrm{N}$ doses $\left(30,70\right.$, and $\left.150 \mathrm{~kg} \mathrm{ha}^{-1}\right)$; and one control treatment, without $\mathrm{N}$ fertilization. Emissions of $\mathrm{N}_{2} \mathrm{O}-\mathrm{N}$, global warming potential (pGWP), emission factors (EF) for mineral fertilizers, grain yield, emission intensity, nitrate, ammonium, $\mathrm{pH}$, and potential redox were quantified. Gas sampling was carried out in two crop seasons of rice cultivation and in one off-season. During the flooded period of the two crop seasons, $\mathrm{N}_{2} \mathrm{O}$ fluxes did not exceed $862.41 \mu \mathrm{g} \mathrm{m}^{-2} \mathrm{~h}^{-1} \mathrm{~N}_{2} \mathrm{O}-\mathrm{N}$; in the off-season, the fluxes varied from -52.95 to $274.34 \mu \mathrm{g} \mathrm{m}^{-2} \mathrm{~h}^{-1} \mathrm{~N}_{2} \mathrm{O}-\mathrm{N}$. Consistent emission peaks were observed in soil draining before harvest, when the highest rate of both $\mathrm{N}$ sources was used, and also in the control treatment in the off-season. Protected urea does not reduce $\mathrm{N}_{2} \mathrm{O}$ emissions or EF. Nitrogen increases the grain yield. Protected urea does not have any effect on the pGWP. The concentrations of $\mathrm{NO}_{3}{ }^{-}$and $\mathrm{NH}_{4}{ }^{+}$in the soil are not related to $\mathrm{N}_{2} \mathrm{O}$ fluxes.
\end{abstract}

Index terms: Oryza sativa, climate change, emission factor, greenhouse gases, nitrogen use efficiency.

\section{Emissão de óxido nitroso em cultivo de arroz inundado em área tropical do Brasil}

Resumo - O objetivo deste trabalho foi avaliar os efeitos dos fertilizantes nitrogenados na dinâmica do $\mathrm{N}$ e na produtividade de arroz (Oryza sativa) inundado em áreas úmidas tropicais Brasileiras. O experimento foi realizado em delineamento de blocos ao acaso, com seis tratamentos: ureia comum e protegida; doses de $\mathrm{N}\left(30,70\right.$ e $\left.150 \mathrm{~kg} \mathrm{ha}^{-1}\right)$ em cobertura; e controle, sem fertilização com N. Foram quantificados emissões de $\mathrm{N}-\mathrm{N}_{2} \mathrm{O}$, potencial de aquecimento global (pGWP), fatores de emissão (EF) para fertilizantes minerais, rendimento de grãos, intensidade de emissão, nitrato, amônio, $\mathrm{pH}$ e potencial redox. As amostragens foram realizadas em duas safras e na entressafra do arroz. Durante o período de inundação das duas safras, os fluxos de $\mathrm{N}-\mathrm{N}_{2} \mathrm{O}$ não excederam $862,41 \mu \mathrm{g} \mathrm{m}^{2} \mathrm{~h}^{1}$; no período de entressafra, os fluxos variaram de $-52,95$ a 274,34 $\mu \mathrm{g} \mathrm{m}^{-2} \mathrm{~h}^{-1} \mathrm{~N}-\mathrm{N}_{2} \mathrm{O}$. Observaram-se picos de emissão consistentes na drenagem do solo, antes da colheita, quando a dose mais alta de ambas as fontes de $\mathrm{N}$ foi utilizada, e também no controle na entressafra. A ureia protegida não reduz as emissões de $\mathrm{N}_{2} \mathrm{O}$ ou EF. O nitrogênio aumenta o rendimento de grãos. A ureia protegida não afeta o pGWP. As concentrações de $\mathrm{NO}_{3}{ }^{-}$e $\mathrm{NH}_{4}{ }^{+}$no solo não estão relacionadas aos fluxos de $\mathrm{N}_{2} \mathrm{O}$.

Termos para indexação: Oryza sativa, mudanças climáticas, fator de emissão, gases de efeito estufa, eficiência de uso de nitrogênio. 


\section{Introduction}

Brazil is the ninth largest rice (Oryza sativa L.) producer in the world (FAO, 2020). More than $80 \%$ of the Brazilian production comes from wetland areas, whose basic cultivation system is irrigated by flood. In 2019, rice grain production in tropical lowlands was approximately $9 \%$ of the national production, and $10 \%$ of the total was produced in flooded systems (Conab, 2020). Because of the modern cultivars, it is possible to have high-quality grain outside Southern Brazil, which contributes to economic and social development, enhancing human life quality in the Cerrado, and collaborates for national food security. However, this demands the increasing use of nitrogen mineral fertilizer in the rice production system that directly influences the emission rates of $\mathrm{N}_{2} \mathrm{O}$, with direct and indirect effects on the emissions of this greenhouse gas (GHG).

High $\mathrm{N}$ rates generally promote higher $\mathrm{N}_{2} \mathrm{O}$ emissions; however, these emissions may vary according to the climate (dry or moisture air condition), soil type and management, $\mathrm{N}$ (source and rates), cultivars, and dry-moisture soil cycles (Linquist et al., 2012; $3^{\mathrm{a}}$ Comunicação..., 2016). Nitrous oxide $\left(\mathrm{N}_{2} \mathrm{O}\right)$ is an important greenhouse gas whose global warming potential is 265 times greater than $\mathrm{CO}_{2}$ (Smith et al., 2014).

Studies carried out in production areas of flooded rice in the world have verified significant $\mathrm{N}_{2} \mathrm{O}$ emissions in those humid areas, both before flooding and after drainage, especially because of nitrogen fertilizer applications (Linquist et al., 2012; AdvientoBorbe et al., 2015; Zschornack et al., 2016). The use of protected nitrogen fertilizers (protected urea) can be a way to reduce $\mathrm{N}$ losses compared with conventional urea (Grohs et al., 2011). There are reports on a positive effect of using protected urea on the $\mathrm{N}_{2} \mathrm{O}$ emissions decrease (Xia et al., 2017; Li et al., 2018). However, there is no consensus on the real advantages of using coated nitrogen fertilizers (Fageria \& Carvalho, 2014). Nevertheless, in the Brazilian tropical lowlands, where the chemical reactions can be intensified because of high temperatures of the air, data on emissions and emission factors are still incipient for greenhouse gases, such as $\mathrm{N}_{2} \mathrm{O}$, for the use of $\mathrm{N}$ fertilizers in flooded rice.
Therefore, studies covering effects of $\mathrm{N}$ fertilizer application on $\mathrm{N}_{2} \mathrm{O}$ emission and emission intensity, in tropical flooded rice systems, are essential to develop strategies for increasing the $\mathrm{N}$ use efficiency from mineral fertilizers, decreasing $\mathrm{N}_{2} \mathrm{O}$ losses to the atmosphere, besides being a tool for public policies for agriculture in Brazil.

The objective of this work was to evaluate the effects of sources and doses of $\mathrm{N}$ fertilizers on the $\mathrm{N}$ dynamics and grain yield of flooded rice cultivation in Brazil.

\section{Materials and Methods}

The study is part of the experiments developed under the international partnership project "NUCLEUS: a virtual joint center to deliver enhanced NUE via an integrated soil-plant system approach for the United Kingdom and Brazil". It was carried out under field conditions, in the 2014/2015 rice crop season, in the 2015 off-season, and in the 2015/2016 crop season, in the experimental station of Palmital Farm, belonging to Embrapa Arroz e Feijão, in the municipality of Goianira, in the state of Goiás, Brazil $\left(16^{\circ} 26^{\prime} 45^{\prime \prime}\right.$, $49^{\circ} 23^{\prime} 31 " \mathrm{~W}$, at $729 \mathrm{~m}$ altitude). According to the Köppen-Geiger's classification, the climate is Aw, with $1,485 \mathrm{~mm}$ annual mean precipitation and $71 \%$ annual mean relative humidity.

The soil is classified as Gleissolo Háplico Ta eutrófico neofluvissólico, according Brazilian Soil Classification System (Santos et al., 2018), i.e., Gleysol, according FAO (IUSS Working Group WRB, 2015), with medium texture, and it has been cultivated with flooded rice for approximately 36 years. Soil chemical characteristics in the 2014/2015 crop season were: $\mathrm{pH}$ $\left(\mathrm{H}_{2} \mathrm{O}\right)$ 5.6; $2.8 \mathrm{cmol}_{\mathrm{c}} \mathrm{dm}^{-3} \mathrm{Ca} ; 0.8 \mathrm{cmol}_{\mathrm{c}} \mathrm{dm}^{-3} \mathrm{Mg} ; 0.2$ cmol $_{\mathrm{c}} \mathrm{dm}^{-3} \mathrm{Al} ; 0.2 \mathrm{cmol}_{\mathrm{c}} \mathrm{dm}^{-3} \mathrm{~K} ; 123.6 \mathrm{mg} \mathrm{dm}^{-3} \mathrm{P} ; 7.4$ $\mathrm{mg} \mathrm{dm}{ }^{-3} \mathrm{Cu} ; 5.9 \mathrm{mg} \mathrm{dm}^{-3} \mathrm{Zn} ; 364.2 \mathrm{mg} \mathrm{dm}^{-3} \mathrm{Fe} ; 24$ $\mathrm{mg} \mathrm{dm}{ }^{-3} \mathrm{Mn} ; 1.8 \%$ total C; and, $0.2 \%$ total N. Soil chemical characteristics in the 2015/2016 crop season were: $\mathrm{pH}\left(\mathrm{H}_{2} \mathrm{O}\right) 5.2 ; 2.0 \mathrm{cmol}_{\mathrm{c}} \mathrm{dm}^{-3} \mathrm{Ca} ; 0.6 \mathrm{cmol}_{\mathrm{c}} \mathrm{dm}^{-3}$ $\mathrm{Mg} ; 0.7 \mathrm{cmol}_{\mathrm{c}} \mathrm{dm}^{-3} \mathrm{Al} ; 0.15 \mathrm{cmol}_{\mathrm{c}} \mathrm{dm}^{-3} \mathrm{~K} ; 43.2 \mathrm{mg} \mathrm{dm}^{-3}$ $\mathrm{P} ; 2.3 \mathrm{mg} \mathrm{dm}^{-3} \mathrm{Cu} ; 3.9 \mathrm{mg} \mathrm{dm}^{-3} \mathrm{Zn} ; 324.2 \mathrm{mg} \mathrm{dm}^{-3} \mathrm{Fe}$; $41 \mathrm{mg} \mathrm{dm}^{-3} \mathrm{Mn} ; 2.3 \%$ total $\mathrm{C}$; and, $0.2 \%$ total $\mathrm{N}$. The soil texture was: $239 \mathrm{~g} \mathrm{~kg}^{-1}$ clay; $242 \mathrm{~g} \mathrm{~kg}^{-1}$ silt; and 519 $\mathrm{g} \mathrm{kg}^{-1}$ sand. 
The experiment was carried out in a randomized complete block design with six treatments, in a $2 \times 3+1$ arrangement, with two nitrogen sources, three $\mathrm{N}$ doses, one control, and three replicates. The treatments were: $\mathrm{N}$ fertilizer source [common urea $(\mathrm{CU})$ and protected urea (PU, urea coated with $0.15 \% \mathrm{Cu}$ plus $0.4 \% \mathrm{~B}$ )]; doses of $\mathrm{N}$ topdressing for each urea type (30, 70, 150 $\mathrm{kg} \mathrm{ha}^{-1}$ ); and a control (without $\mathrm{N}$ application).

Rice 'BRS Catiana' was sown in the 2014/2015 and 2015/2016 crop seasons, in twenty-one experimental plots of $5.5 \times 3.3 \mathrm{~m}$, with $17 \mathrm{~cm}$ between rows, using 85 seed per linear meter of row. At the sowing in the 2014/2015 crop season, $6.5 \mathrm{~kg} \mathrm{ha}^{-1} \mathrm{~N}$ (in the form of urea), $40 \mathrm{~kg} \mathrm{ha}^{-1} \mathrm{P}_{2} \mathrm{O}_{5}$, and $60 \mathrm{~kg} \mathrm{ha}^{-1} \mathrm{~K}_{2} \mathrm{O}$ were used. In the 2015/2016 crop season, the fertilization was performed with $20 \mathrm{~kg} \mathrm{ha}^{-1} \mathrm{~N}$ (urea), $40 \mathrm{~kg} \mathrm{ha}^{-1}$ $\mathrm{P}_{2} \mathrm{O}_{5}$, and $50 \mathrm{~kg} \mathrm{ha}^{-1} \mathrm{~K}_{2} \mathrm{O}$. The doses of $\mathrm{P}$ and $\mathrm{K}$ were calculated according to the soil chemical analysis. The recommended fertilizer dose for rice cultivars ranges from 90 and $120 \mathrm{~kg} \mathrm{ha}^{-1} \mathrm{~N}$ (Fageria et al., 2003).

Nitrogen was applied twice, by topdressing, in the rice phenological stages V3-V4 (beginning of the tillering, 23 days after sowing) and in V7-V8 (effective tillering, 45 days after sowing), respectively. The topdressing $\mathrm{N}$ need was determined with chlorophyll meter SPAD-502 (Minolta, 1989) in rice leaves, to monitor the $\mathrm{N}$ status in rice. When the $\mathrm{N}$ sufficiency index (NSI), calculated according Santos et al. (2019), was less than or equal to $90 \%, 30 \mathrm{~kg} \mathrm{ha}^{-1} \mathrm{~N}$ was applied as the first topdressing, except for the control treatment, and the remaining $\mathrm{N}$ was applied as the second topdressing to complete the doses, for each source. The area was flooded three days after the first topdressing, with a constant water depth of approximately $10 \mathrm{~cm}$, until near the rice harvest. The $\mathrm{N}_{2} \mathrm{O}$ emissions were quantified using the closed static chamber method (Hutchinson \& Mosier, 1981). $\mathrm{NH}_{4}^{+}$ and $\mathrm{NO}_{3}$ were extracted according Tedesco et al. (1995) and analyzed with the colorimetric method by flow injection analysis (FIA), according to Greenberg (1984), in soil and soil solution. Soil solution $\mathrm{pH}$ and potential redox $(\mathrm{Eh})$ were obtained using the electrode method (Donagema, 2011).

Gas sampling started one day after sowing. It was performed twice a week in the no flooded period, and once a week during the flooded period. After each $\mathrm{N}$ fertilization, the sampling was carried out daily for a period of seven days, while, in the off-season, samplings were biweekly. For the air sampling, in the 2014/2015 crop season, there was one chamber for each plot, in a rectangular shape metal basis $(40 \times 60 \times 15 \mathrm{~cm})$, partially inserted into the ground $(5 \mathrm{~cm})$. During the growth of rice plants, an extender was inserted between the basis and the top of the chamber. In the 2015/2016 crop season, the static chambers used had a circular shape made of plastic $(20 \mathrm{~cm}$ height and 17.5 $\mathrm{cm}$ radius), partially inserted into the ground $(10 \mathrm{~cm})$, with a plastic lid. In both chamber shapes there were a hole in the lid for sampling gases using a manual pump. A $38 \mathrm{~cm}$ high extender was used, according to growing plants. The chambers were positioned to achieve as many rows as possible. Air samplings were performed in the morning, between 9:00 and 11:00 h, according to Jantalia et al. (2008), at the preestablished time intervals of 0,15 , and $30 \mathrm{~min}$ after closing the chambers. Water was added to the top of the basis and extenders (junctions) to guarantee no gas escaping. Before and after each air sampling, the temperatures of the inner chamber, soil, and air were monitored with a digital thermometer.

The concentrations of $\mathrm{N}_{2} \mathrm{O}$ were determined using a gas chromatographer GC 2014 "Greenhouse" (Shimadzu Co., Tokyo, Japan). The rate of gas increase over time was calculated considering the linear adjustment model $(\Delta \mathrm{C} / \Delta \mathrm{t})$, for the increases of gas that presented linear adjustment. When the increases of gas did not show linear adjustment, the Hutchinson \& Mosier model (Venterea et al., 2012) was used, which is described by the equation

$\mathrm{F}=(\mathrm{C} 1-\mathrm{C} 0) 2 /[\mathrm{t} 1 \times(2 \times \mathrm{C} 1-\mathrm{C} 2-\mathrm{C} 0)] \times \ln [(\mathrm{C} 1-\mathrm{C} 0) /$ (C2 - C1)],

in which: $\mathrm{F}$ is the flux ( $\mu \mathrm{L} \mathrm{L}^{-1} \mathrm{~h}^{-1}$ gas); $\mathrm{C} 0, \mathrm{C} 1$, and $\mathrm{C} 2$ are the gas concentrations $\left(\mathrm{ppb}-\mathrm{N}_{2} \mathrm{O}\right)$ in the measuring chamber, at times 0,1 , and 2, respectively; and $\mathrm{t} 1$ is the interval between sampling times (h).

After these criteria, $\mathrm{N}_{2} \mathrm{O}$ flux was converted from volumetric unit $\left(\mu \mathrm{L} \mathrm{m}^{-2} \mathrm{~h}^{-1}\right)$ to mass unit $\left(\mu \mathrm{g} \mathrm{m}^{-2} \mathrm{~h}^{-1}\right)$ using the ideal gas law: $\mathrm{PV}=\mathrm{nRT}$, in which: $\mathrm{P}$ is the pressure (atm); V is the volume (L); $\mathrm{n}$ is the number of moles of gas ( $\mu \mathrm{mol})$; $\mathrm{R}$ is the constant of the ideal gas; and $\mathrm{T}$ is the temperature $(\mathrm{K})$. Only fluxes with coefficients of determination $\left(\mathrm{R}^{2}\right)$ greater than 0.8 
were considered, otherwise, data were considered as missing.

Total $\mathrm{N}_{2} \mathrm{O}$ emission was calculated from the integration of the daily $\mathrm{N}_{2} \mathrm{O}$ fluxes throughout the evaluation period. The emission factor (EF) from the $\mathrm{N}$ fertilizer application was calculated as the proportion of $\mathrm{N}_{2} \mathrm{O}-\mathrm{N}$ emitted in the evaluation period related to the total synthetic $\mathrm{N}$ applied, according to the following equation (Carvalho et al., 2018):

$\mathrm{EF}_{\mathrm{N} 2 \mathrm{O}}(\%)=\left[\left(\mathrm{N}_{2} \mathrm{O}-\mathrm{N}_{\text {treatment }}-\mathrm{N}_{2} \mathrm{O}-\mathrm{N}_{\text {control }}\right) / \mathrm{N}\right.$ applied in the treatment] $\times 100$,

in which: $\mathrm{EF}_{\mathrm{N} 2 \mathrm{O}}$ is the nitrous oxide emission factor; $\mathrm{N}_{2} \mathrm{O}-\mathrm{N}_{\text {treatment }}$ is the $\mathrm{N}$ emitted from the soil as nitrous oxide from $\mathrm{N}$ fertilization $\left(\mathrm{kg} \mathrm{ha}^{-1}\right) ; \mathrm{N}_{2} \mathrm{O}-\mathrm{N}_{\text {control }}$ is the $\mathrm{N}$ emitted from the soil as nitrous oxide without $\mathrm{N}$ fertilization $\left(\mathrm{kg} \mathrm{ha}^{-1}\right)$.

The partial global warming potential (pGWP) was calculated by converting $\mathrm{N}_{2} \mathrm{O}$ emissions to $\mathrm{CO}_{2}$ equivalent ( $\mathrm{kg} \mathrm{ha}^{-1} \mathrm{CO}_{2 \mathrm{eq}}$ ), according to the expression pGWP $=\left(\mathrm{N}_{2} \mathrm{O} \times 265\right)$, in which: $\mathrm{N}_{2} \mathrm{O}$ corresponds to the accumulated $\mathrm{N}_{2} \mathrm{O}$ emissions during the crop seasons $\left(\mathrm{kg} \mathrm{ha}^{-1}\right)$; and the GWP values for $\mathrm{N}_{2} \mathrm{O}$ consider an atmospheric residence time of 100 years (Forster et al., 2007). In no flooded period, together with air sampling, soil samples were collected at $0-10 \mathrm{~cm}$ soil depth to determine the gravimetric moisture, nitrate $\left(\mathrm{NO}_{3}{ }^{-}\right)$, and ammonium $\left(\mathrm{NH}_{4}^{+}\right)$in the soil. When the area was flooded, the soil solution was collected using commercial soil solution extractors, which are pipes of $60 \mathrm{~cm}$ high with a pore cap of $5 \mathrm{~cm}$ length at one end, inserted $15 \mathrm{~cm}$ into the ground to allow of the capture of soil solution at 10 to $15 \mathrm{~cm}$ soil depth, to determine soil $\mathrm{pH}$ and redox potential (Eh), in addition to $\mathrm{NO}_{3}{ }^{-}$ and $\mathrm{NH}_{4}{ }^{+}$levels.

To determine grain yield, four lines of $2.5 \mathrm{~m}$ were harvested and weighted, to obtain data $\left(\mathrm{kg} \mathrm{ha}^{-1}\right)$. Emission intensity was calculated as being accumulated $\mathrm{N}_{2} \mathrm{O}-\mathrm{N}$ emission split rice grain yield, as follows: $\mathrm{I}=\mathrm{N} /$ yield, in which: $\mathrm{I}$ is the emission intensity $\left(\mathrm{N}_{2} \mathrm{O}-\mathrm{N} \mathrm{g} \mathrm{kg}{ }^{-1}\right.$ grain); $\mathrm{N}=\mathrm{N}_{2} \mathrm{O}$ emitted $\left(\mathrm{g} \mathrm{ha}^{-1}\right)$; and yield is expressed in kilogram per hectare.

Descriptive analyses were used to explore the daily $\mathrm{N}_{2} \mathrm{O}$ emissions and the soil variables. Accumulated $\mathrm{N}_{2} \mathrm{O}$ emissions were evaluated from the sources of variation of the experiment. Correlation and regression analyses were performed to verify $\mathrm{N}_{2} \mathrm{O}$ flux dependence on the nitrate, ammonium, Eh, and $\mathrm{pH}$ levels. Statistical analyzes were performed using the $\mathrm{R}$ program ( $\mathrm{R}$ Core Team, 2017).

\section{Results and Discussion}

The $\mathrm{N}_{2} \mathrm{O}-\mathrm{N}$ emission peaks were observed after rice sowing in all treatments (Figure 1), and may be resulted from the application of $\mathrm{N}$ fertilizer at this stage, which may have improved $\mathrm{N}$ releasing to soil. In the flooded period of the 2014/2015 and 2015/2016 crop seasons, $\mathrm{N}_{2} \mathrm{O}$ fluxes did not exceed $862.41 \mu \mathrm{g} \mathrm{m}^{-2} \mathrm{~h}^{-1}$ $\mathrm{N}_{2} \mathrm{O}-\mathrm{N}$, and there were no statistical differences between sources or rates. However, consistent emission peaks were observed when the highest $\mathrm{N}$ rate was used for both sources, in draining soil before harvest. The main pathway of nitrous oxide emission from the ricesoil system depends on the soil water status, that is, when the soil is flooded, the emission is predominantly through the rice plants, while in the absence of floodwater, $\mathrm{N}_{2} \mathrm{O}$ is emitted mainly through the soil surface, by soil microorganisms, (Yan et al., 2000; Timilsina et al., 2020). According to Ponnamperuma (1972), in anaerobic conditions, there is a high consumption of electrons due to the soil reduction process, which reduces the availability of nitrate and, consequently, $\mathrm{N}_{2} \mathrm{O}$. In addition, the water depth would act as a physical barrier, limiting the diffusion of $\mathrm{N}_{2} \mathrm{O}$ from the soil to the atmosphere. In the present study, an increase of $\mathrm{N}_{2} \mathrm{O}$ emissions from the soil was observed in the soil drainage process, which confirms that this process created ideal conditions for nitrification and denitrification, occurring in microsites of inner soil aggregates (Adviento-Borbe et al., 2015), enhancing emissions of $\mathrm{N}_{2} \mathrm{O}-\mathrm{N}$ from the soil.

At the beginning of the off-season period, $\mathrm{N}_{2} \mathrm{O}-\mathrm{N}$ emission peaks were observed in the treatment PU 70 (274.34 $\mu \mathrm{g} \mathrm{m}^{-2} \mathrm{~h}^{-1} \mathrm{~N}_{2} \mathrm{O}-\mathrm{N}$ ), which may be resulted from late emissions when protectedurea wasused(Figure 1C). Subsequently, the $\mathrm{N}_{2} \mathrm{O}-\mathrm{N}$ peaks remained relatively low, close to zero, and constant until the beginning of the 2015/2016 crop season, especially because of the rain absence in this period of the year (from May to October), which is a very common condition in Brazilian Cerrado. Emissions during the off-season varied from -52.95 to $274.34 \mu \mathrm{g} \mathrm{m}^{-2} \mathrm{~h}^{-1} \mathrm{~N}_{2} \mathrm{O}-\mathrm{N}$. 

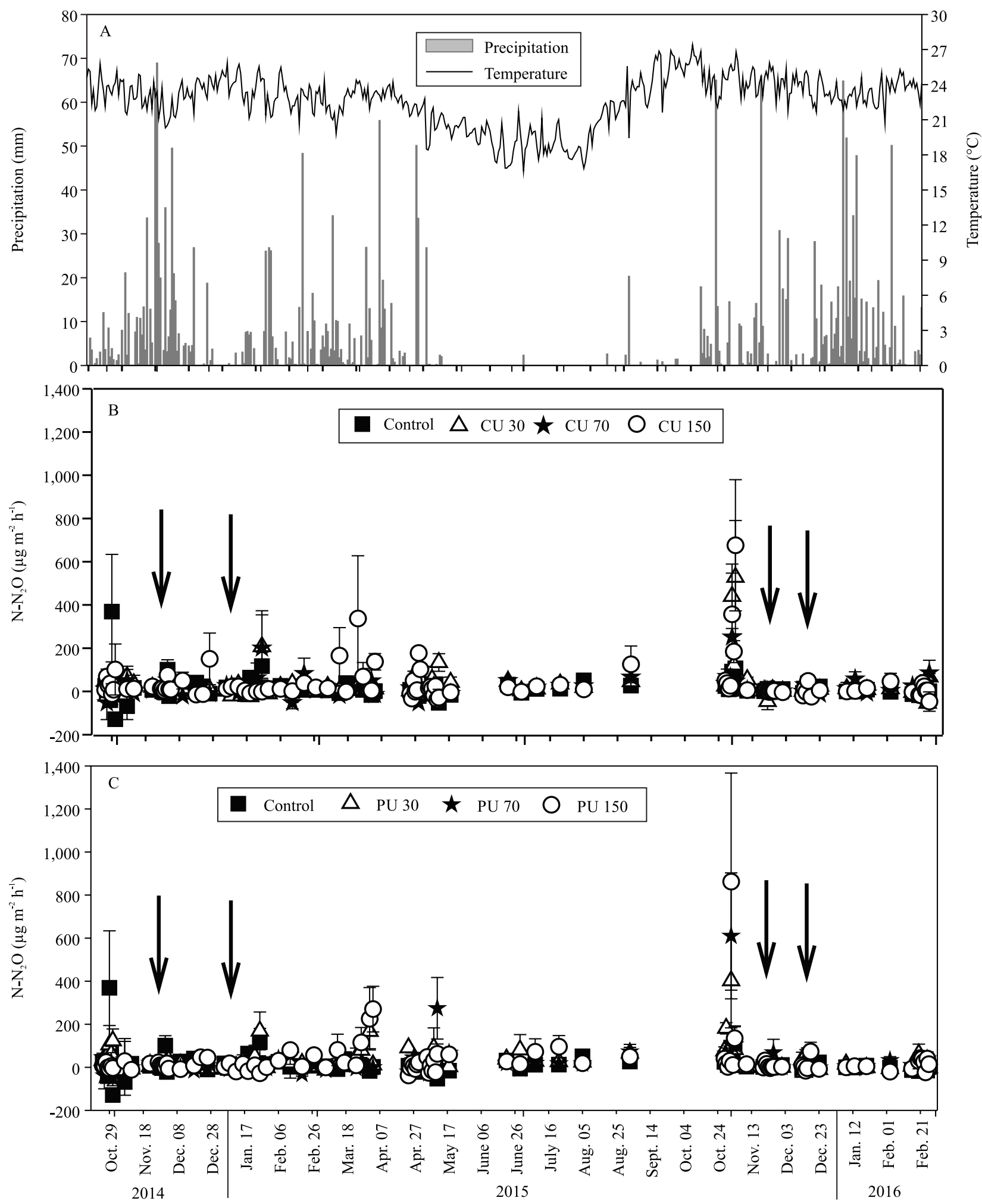

Figure 1. Monthly air temperature and precipitation (A), and $\mathrm{N}_{2} \mathrm{O}-\mathrm{N}$ flux from the application of common urea (CU) (B) and protected urea (PU) (C), at the doses of 30,70, and $150 \mathrm{~kg} \mathrm{ha}^{-1} \mathrm{~N}$ to flooded rice (Oryza sativa) cultivation in tropical wetland. The arrows represent the application dates of nitrogen fertilizer (November 26, 2014, January 04, 2015, November 17, 2015, and December 12, 2015). 
However, no significant differences were observed in the $\mathrm{N}_{2} \mathrm{O}-\mathrm{N}$ emissions related to $\mathrm{N}$ rates, which corroborate the results described by Pittelkow et al. (2013), when studying GHG in flooded rice cultivation in response to the addition of $\mathrm{N}$.

In the 2015/2016 crop season, peaks ranged from -54.28 to $862.41 \mu \mathrm{g} \mathrm{m}^{-2} \mathrm{~h}^{-1} \mathrm{~N}_{2} \mathrm{O}-\mathrm{N}$, and the highest peaks were recorded in the treatments PU $150(862.41$ $\left.\mu \mathrm{g} \mathrm{m}^{-2} \mathrm{~h}^{-1} \mathrm{~N}_{2} \mathrm{O}-\mathrm{N}\right)$, CU $150\left(675.85 \mu \mathrm{g} \mathrm{m}^{-2} \mathrm{~h}^{-1} \mathrm{~N}_{2} \mathrm{O}-\mathrm{N}\right)$, PU 70 (610.54 $\left.\mu \mathrm{g} \mathrm{m}^{-2} \mathrm{~h}^{-1} \mathrm{~N}_{2} \mathrm{O}-\mathrm{N}\right)$, and CU 30 (528.25 $\left.\mu \mathrm{g} \mathrm{m} \mathrm{m}^{-2} \mathrm{~h}^{-1} \mathrm{~N}_{2} \mathrm{O}-\mathrm{N}\right)$. All peaks described in both crop seasons were observed during the period when the soil was not flooded, but humid after rain occurrences, which enhances $\mathrm{N}_{2} \mathrm{O}$ emissions similarly to that of the drainage preharvest condition (Zou et al., 2007). The values of the highest fluxes observed in the 2015/2016 crop season - just after sowing (on October 24, 2015) and before flooding (on December 03, 2015) - could be related to the sowing fertilization with mineral $\mathrm{N}$ (Figure 1) associated to the occurrence of precipitations in the period, especially that with $65 \mathrm{~mm}$ on October 31 , 2016. Precipitations can affect the extent of anaerobic sites in the soil due to the increase of soil moisture and water-filled pore space (WFPS), which influences the $\mathrm{N}_{2} \mathrm{O}-\mathrm{N}$ emission rates both by the nitrification process, when the WFPS volume is $<60 \%$, and the denitrification process, when the WFPS volume is $>80 \%$ (Signor \& Cerri, 2013).

In the experimental plots, a decrease of nitrate contents was observed after flooding and, at the same time, an increase of ammonium soil contents, irrespectively of $\mathrm{N}$ rates or sources (Figure 2). Initial losses of $\mathrm{NO}_{3}{ }^{-}$, soon after flooding, result from the absorption by plants, leaching in soil profile, ammonia volatilization and, mainly, from the denitrification of gaseous $\mathrm{N}_{2} \mathrm{O}$ and $\mathrm{N}_{2}$ (Camargo et al., 1999). Despite the use of different $\mathrm{N}$ sources, no statistical differences were observed between both sources for releasing nitrate or ammonium, during the flooded period, and soil $\mathrm{NO}_{3}{ }^{-}$availability also remained close to zero, as expected due denitrification process, while a greater amount of $\mathrm{NH}_{4}^{+}$was observed just after the first topdressing, which corroborates the observations by Pittelkow et al. (2013) in flooded rice. The main reason for these results is the kind of inhibitor associated with urea, which when used in soils with low organic matter content $(\sim 2 \%$ total $C)$ could impact negatively the denitrification process.

Grain yield presented a quadratic response with the increase of $\mathrm{N}$ rates in the range $0-150 \mathrm{~kg} \mathrm{ha}^{-1}$. By the regression equation, the maximum grain yield was estimated at the dose of $129 \mathrm{~kg} \mathrm{ha}^{-1} \mathrm{~N}$, and the maximum economic dose, which reaches $90 \%$ of the maximum yield, was approximately $64 \mathrm{~kg} \mathrm{ha}^{-1} \mathrm{~N}$ (Figure 3). This dose is below that found by Fageria et al. (2003), who have obtained approximately $90 \mathrm{~kg} \mathrm{ha}^{-1} \mathrm{~N}$ as the average economic dose of three years of experimentation with flooded rice, in a Gleissolo Háplico soil, in the conditions of tropical wetland. These results are very important not just for environment, by reducing $\mathrm{N}$ inputs into rice fields, but, specially from stakeholders' point of view, because this could promote a positive impact, by reducing production costs and increasing farmer profits, and contribute to sustainability of tropical flooded rice production system.

The $\mathrm{N}_{2} \mathrm{O}$ emission factor (EF) of fertilizers showed no statistical differences between common and protected urea, and the values ranged from 0.39 to $1.08 \%$ (Table 1). However, the values found in the present work were higher than those found by Akiyama et al. (2005), who did a meta-analysis using 113 measurements from 17 sites from China, and concluded that the $\mathrm{N}_{2} \mathrm{O}$ EF in rice cultivation irrigated by continuous flooding is on average $0.22 \pm 0.24 \%$ of the applied $\mathrm{N}$. The findings for EF of the present work are also higher than the standard value $(0.3 \%)$ considered by the IPCC (Eggleston et al., 2006) for flooded rice systems. Several studies have indicated that this factor can be quite variable depending on the type of soil, environment, and soil and crop management (Linquist et al., 2012; Smith et al., 2014; 3 a Comunicação..., 2016).

The pGWP of the $\mathrm{N}_{2} \mathrm{O}$ showed no significant differences among treatments (Table 2). The pGWP relates GHG emissions to grain yields. Through the pGWP is possible to know how much each kilogram of produced grain emitted GHG in $\mathrm{CO}_{2}$ equivalent. In management systems that are difficult to reduce $\mathrm{N}_{2} \mathrm{O}$ emissions, increasing crop yield is an alternative to reduce the emission intensity (pGWP / grain yields). However, in the present study, the evaluated treatments had no influence on pGWP, and the sources did not

Pesq. agropec. bras., Brasília, v.55, e01497, 2020

DOI: 10.1590/S1678-3921.pab2020.v55.01497 

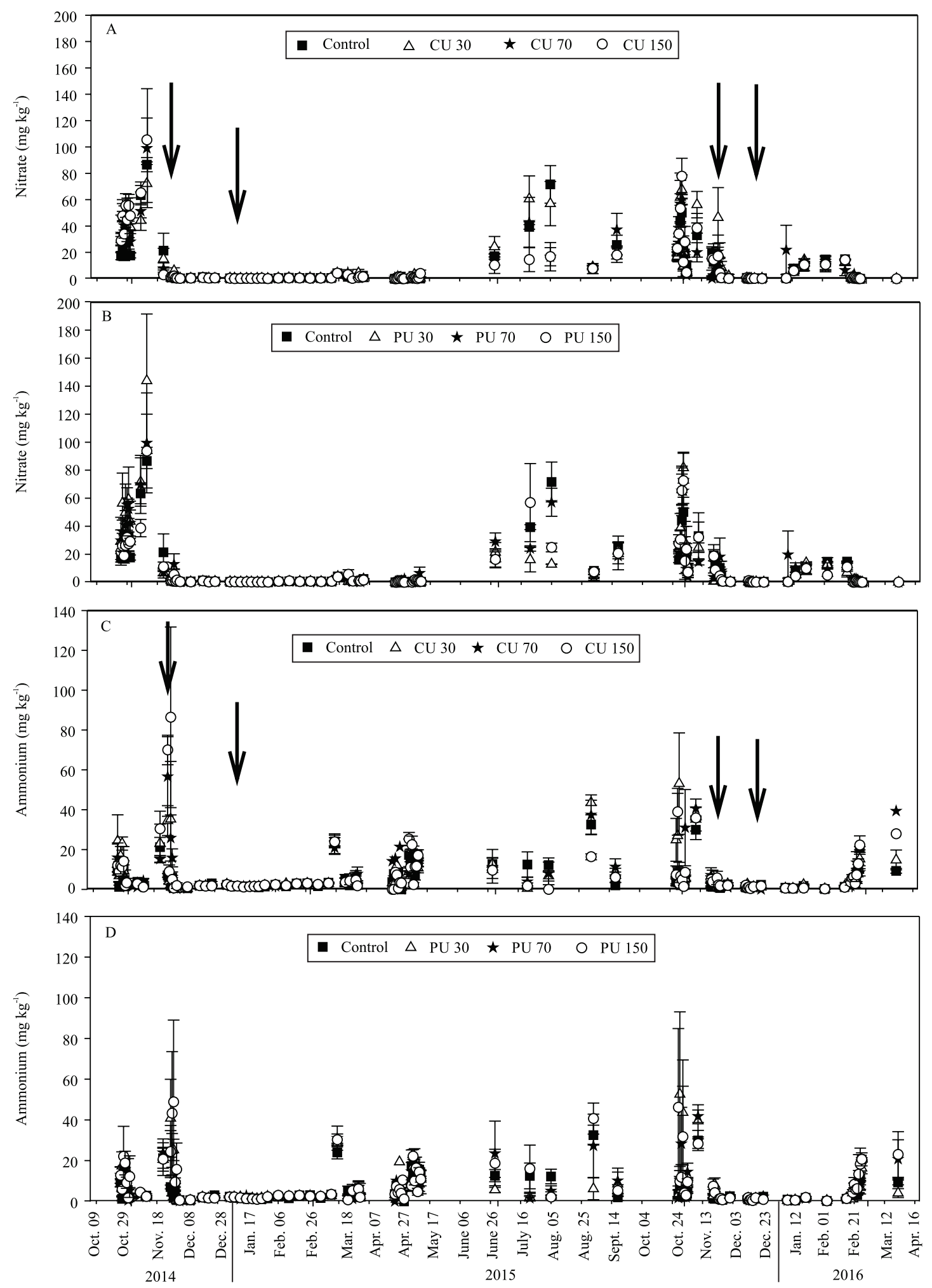

Figure 2. Variation of nitrate content (A and B) and ammonium content (C and D) in soil and soil solution, during flooded rice (Oryza sativa) cultivation in tropical wetland. Treatments: common urea (CU) and protected urea (PU) at the doses of 30,70 , and $150 \mathrm{~kg} \mathrm{ha}^{-1} \mathrm{~N}$. The arrows represent the application dates of nitrogen fertilizer (November 26, 2014, January 04, 2015, November 17, 2015, and December 12, 2015). 


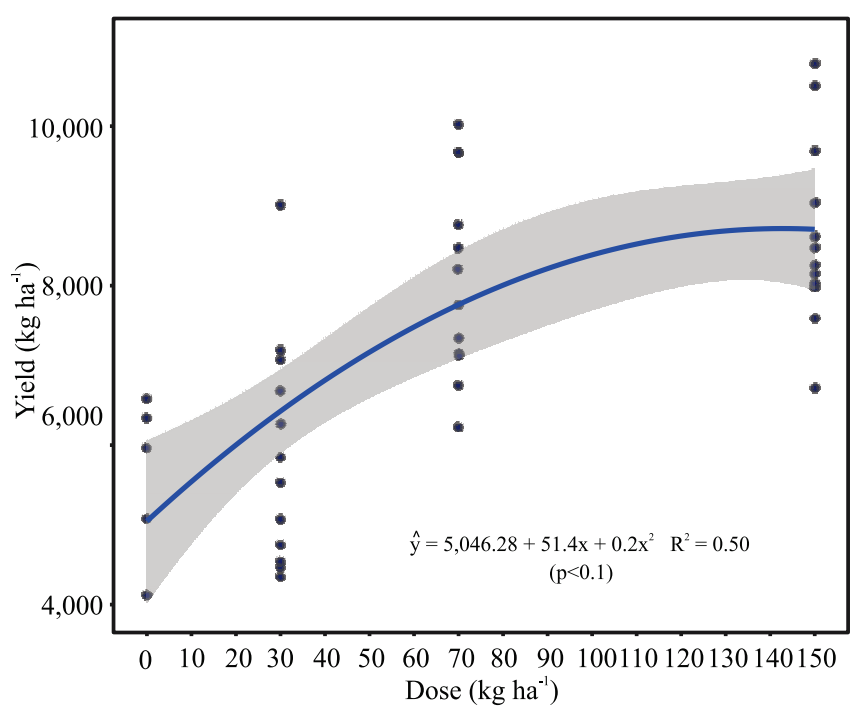

Figure 3. Effect of the doses of mineral nitrogen fertilizer on the yield of tropical flooded rice 'BRS Catiana' (Oryza sativa) in a Gleissolo Háplico (Gleysol).

Table 1. Nitrogen emission factor in flooded rice (Oryza sativa) cultivation in tropical wetland from fertilization with common urea (CU) and protected urea (PU), in two crop seasons and one off-season ${ }^{(1)}$.

\begin{tabular}{lcccc}
\hline Treatment & \multicolumn{4}{c}{ Emission factor (\%) } \\
\cline { 2 - 5 } & $2014 / 2015$ & Off-season & $2015 / 2016$ & General \\
\hline Common urea & $0.56^{\text {ns }}$ & $0.76^{\text {ns }}$ & $1.00^{\text {ns }}$ & $0.78^{\text {ns }}$ \\
Protected urea & $0.43^{\text {ns }}$ & $1.08^{\text {ns }}$ & $0.39^{\text {ns }}$ & $0.63^{\text {ns }}$ \\
\hline
\end{tabular}

${ }^{(1)}$ Means followed by equal letters do not differ, by the Tukey's test, at $5 \%$ probability. General, mean of the three periods, two crop seasons and off-season.

influence the grain yield of flood-irrigated rice 'BRS Catiana'.

The results of the research show the importance of studies to understand the behavior of GHG in tropical wetland areas. They show that emissions can be affected by climatic conditions, such as precipitation, by the management of $\mathrm{N}$ fertilization, and by other factors.

\section{Conclusions}

1. Protected urea coated with $0.15 \% \mathrm{Cu}$ plus $0.4 \%$ $\mathrm{B}$ does not reduce $\mathrm{N}_{2} \mathrm{O}$ emissions and the emission
Table 2. Partial global warming potential (pGWP), grain yield of rice, and greenhouse gas (GHG) emission intensity in a tropical wetland cultivated with the flooded rice 'BRS Catiana' (Oryza sativa), in 2014/2015 and 2015/2016 crop seasons.

\begin{tabular}{lccc}
\hline Treatment & $\begin{array}{c}\mathrm{pGWP} \\
\left(\mathrm{kg} \mathrm{ha}^{-1} \mathrm{CO}_{2 \mathrm{eq}}\right)\end{array}$ & $\begin{array}{c}\text { Grain yield } \\
\left(\mathrm{kg} \mathrm{ha}^{-1}\right)\end{array}$ & $\begin{array}{c}\text { Emission intensity } \\
\left(\mathrm{kg}^{2} \mathrm{CO}_{2 \mathrm{eq}} \mathrm{kg}^{-1} \text { grains }\right)\end{array}$ \\
\hline \multicolumn{3}{c}{$2014 / 2015$ Crop season } \\
T0 & $129^{\text {ns }}$ & 5264 & 0.025 \\
CU 30 & $202^{\text {ns }}$ & 5367 & 0.038 \\
CU 70 & $160^{\text {ns }}$ & 7498 & 0.021 \\
CU 150 & $447^{\text {ns }}$ & 7487 & 0.060 \\
PU 30 & $240^{\text {ns }}$ & 6154 & 0.039 \\
PU 70 & $66^{\text {ns }}$ & 7288 & 0.009 \\
PU 150 & $298^{\text {ns }}$ & 8091 & 0.037 \\
\hline & & $2015 / 2016$ Crop season \\
T0 & $66^{\text {ns }}$ & 6156 & 0.011 \\
CU 30 & $270^{\text {ns }}$ & 5235 & 0.052 \\
CU 70 & $114^{\text {ns }}$ & 8219 & 0.014 \\
CU 150 & $291^{\text {ns }}$ & 8929 & 0.033 \\
PU 30 & $119^{\text {ns }}$ & 6853 & 0.017 \\
PU 70 & $157^{\text {ns }}$ & 9388 & 0.017 \\
PU 150 & $132^{\text {ns }}$ & 10110 & 0.013 \\
\hline
\end{tabular}

T0, control; CU, common urea at the doses 30,70 , and $150 \mathrm{~kg} \mathrm{ha}^{-1}$; PU, protected urea (PU) at the doses 30,70 , and $150 \mathrm{~kg} \mathrm{ha}^{-1}$.

factor, when compared to common urea in irrigated flooded rice (Oryza sativa).

2. Protected urea coated with $0.15 \% \mathrm{Cu}$ plus $0.4 \% \mathrm{~B}$ does not have any effect on the partial global warming potential (pGWP).

3. The concentrations of $\mathrm{NO}_{3}{ }^{-}$and $\mathrm{NH}_{4}{ }^{+}$in the soil or solution are not related to $\mathrm{N}_{2} \mathrm{O}$ fluxes.

\section{Acknowledgments}

To Fundação de Amparo à Pesquisa do Estado de São Paulo (Fapesp), to Fundação de Amparo à Pesquisa do Estado de Goiás (Fapeg), to Fundação de Amparo à Pesquisa do Estado do Maranhão (Fapema), and to the Biotechnology and Biological Sciences Research Council (BBSRC), for financial support; to Empresa Brasileira de Pesquisa Agropecuária (Embrapa), for financial and technical support; to Coordenação de Aperfeiçoamento de Pessoal de Nível Superior (Capes, finance code 001), for fellowship; and to Conselho Nacional de Desenvolvimento Científico e Tecnológico (CNPq, process number 301844/2019-4), for fellow PQ2 granted to sixth author. 


\section{References}

$3^{\text {a }}$ COMUNICAÇÃO Nacional do Brasil à Convenção-Quadro das Nações Unidas sobre Mudança do Clima. Brasília: MTCI, 2016. v.3, 336p.

ADVIENTO-BORBE, M.A.; PADILLA, G.N.; PITTELKOW, C.M.; SIMMONDS, M.; van KESSEL, C.; LINQUIST, B. A. Methane and nitrous oxide emissions from flooded rice systems following the end-of-season drain. Journal of Environmental Quality, v.44, p.1071-1079, 2015. DOI: https://doi.org/10.2134/ jeq2014.11.0497.

AKIYAMA, H.; YAGI, K.; YAN, X. Direct $\mathrm{N}_{2} \mathrm{O}$ emissions from rice paddy fields: summary of available data. Global Biogeochemical Cycles, v.19, p.1-10, 2005. DOI: https://doi.org/10.1029/2004GB002378.

CAMARGO, F.A. de O.; SANTOS, G. de A.; ZONTA, E. Alterações eletroquímicas em solos inundados. Ciência Rural, v.29, p.171-180, 1999. DOI: https://doi.org/10.1590/S010384781999000100032 .

CARVALHO, G.D.; MADARI, B.E.; CARVALHO, M.T. de M.; SILVA, M.A.S. da; SANTOS, A.B. dos; COSTA, A.R. da; CORREA, R.S.; OLIVEIRA, J. de M.; LEAL, W.G. de O.; SOUZA, D.M. de; MATSUSHIGE, I.; SANTOS, R.C.G. dos. Impacto do manejo da adubação nitrogenada sobre a emissão de gás de efeito estufa óxido nitroso e a produtividade de arroz irrigado no Cerrado. Santo Antônio de Goiás: Embrapa Arroz e Feijão, 2018. 23p. (Embrapa Arroz e Feijão. Boletim de pesquisa e desenvolvimento, 52).

CONAB. Companhia Nacional de Abastecimento. Série histórica das safras: arroz irrigado. Disponível em: $<$ https:// www.conab.gov.br/info-agro/safras/serie-historica-das-safras/ item/download/34169_fdfbf5a7e0fb804900e84da6e58127c9>. Acesso em: 26 nov. 2020 .

DONAGEMA, G.K.; CAMPOS, D.V.B. de; CALDERANO, S.B.; TEIXEIRA, W.G.; VIANA, J.H.M. (Org.). Manual de métodos de análise de solo. 2.ed. rev. Rio de Janeiro: Embrapa Solos, 2011. 230p. (Embrapa Solos. Documentos, 132).

EGGLESTON, H.S.; BUENDIA, L.; MIWA, K.; NGARA, T.; TANABE, K. (Ed.). 2006 IPCC Guidelines for National Greenhouse Gas Inventories. Hayama: Institute for Global Environmental Strategies, 2006. IPCC 2006.

FAGERIA, N.K.; CARVALHO, M.C.S. Comparison of conventional and polymer coated urea as nitrogen sources for lowland rice production. Journal of Plant Nutrition, v.37, p.13581371, 2014. DOI: https://doi.org/10.1080/01904167.2014.888736.

FAGERIA, N.K.; STONE, L.F.; SANTOS, A.B. dos. Manejo da fertilidade do solo para o arroz irrigado. Santo Antônio de Goiás: Embrapa Arroz e Feijão, 2003. 250p.

FAO. Food and Agriculture Organization of the United Nations. Faostat: crops. 2020. Available at: <http://www.fao.org/faostat/ en/\#data/QC>. Accessed on: Nov. 242020.

FORSTER, P.; RAMASWAMY, V.; ARTAXO, P.; BERNTSEN, T.; BETTS, R.; FAHEY, D.W. ; HAYWOOD, J.; LEAN, J.; LOWE, D.C.; MYHRE, G.; NGANGA, J.; PRINN, R.; RAGA, G.;
SCHULZ, M.; VAN DORLAND, R. FORSTER, P.; ANDREWS, T.; GOOD, P.; GREGORY, J.M.; JACKSON, L.S.; ZELINKA, $M$. Changes in atmospheric constituents and in radiative forcing. In: SOLOMON, S.; QIN, D.; MANNING, M.; MARQUIS, M.; AVERYT, K.; TIGNOR, M.M.B.; MILLER JR., H.L.; CHEN, Z. (Ed.). Climate change 2007: the physical science basis. Contribution of Working Group I to the Fourth Assessment Report of the Intergovernmental Panel on Climate Change. Cambridge: Cambridge University Press, 2007. p.129-234.

GREENBERG, A.E. Advances in standard methods for the examination of water and wastewater. In: ANNUAL AWWA WATER QUALITY TECHNOLOGY CONFERENCE, 1984, Denver. Proceedings. Denver: American Works Association, 1984.

GROHS, M.; MARCHESAN, E.; SANTOS, D.S.; MASSONI, P.F.S.; SARTORI, G.M.S.; FERREIRA, R.B. Resposta do arroz irrigado ao uso de inibidor de urease em plantio direto e convencional. Ciência Agrotecnologia, v.35, p.336-345, 2011. DOI: https://doi.org/10.1590/S1413-70542011000200015.

HUTCHINSON, G.L.; MOSIER, A.R. Improved soil cover method for field measurement of nitrous oxide fluxes. Soil Science Society of America Journal, v.45, p.311-316, 1981. DOI: https://doi.org/10.2136/sssaj1981.03615995004500020017x.

IUSS WORKING GROUP WRB. World Reference Base for Soil Resources 2014: International soil classification system for naming soils and creating legends for soil maps: update 2015. Rome: FAO, 2015. 182p. (FAO. World Soil Resources Report 106).

JANTALIA, C.P.; SANTOS, H.P. dos; URQUIAGA, S.; BODDEY, R.M.; ALVES, B.J.R. Fluxes of nitrous oxide from soil under different crop rotations and tillage systems in the South of Brazil. Nutrient Cycling in Agroecosystems, v.82, p.161-173, 2008. DOI: https://doi.org/10.1007/s10705-008-9178-y.

LI, J.; LI, Y.; WAN, Y.; WANG, B.; WAGAS, M.A.; CAI, W.; GUO, C.; ZHOU, S.; SU, R.; QIN, X.; GAO, Q.; WIKES, A. Combination of modified nitrogen fertilizers and water saving irrigation can reduce greenhouse gas emissions and increase rice yield. Geoderma, v.315, p.1-10, 2018. DOI: https://doi.org/10.1016/j.geoderma.2017.11.033.

LINQUIST, B.A.; ADVIENTO-BORBE, M.A.; PITTELKOW, C.M.; van KESSEL, C.; van GROENIGEN, K.J. Fertilizer management practices and greenhouse gas emissions from rice systems: a quantitative review and analysis. Field Crops Research, v.135, p.10-21, 2012. DOI: https://doi.org/10.1016/j. fcr.2012.06.007.

MINOLTA. Minolta Camera Co., Ltd. Manual for chlorophyll meter SPAD 502. Osaka: Minolta Radiometric Instruments Divisions, 1989. 22p.

PITTELKOW, C.M.; ADVIENTO-BORBE, M.A.; HILL, J.E.; SIX, J.; VAN KESSEL, C.; LINQUIST, B.A. Yield-scaled global warming potential of annual nitrous oxide and methane emissions from continuously flooded rice in response to nitrogen input. Agriculture, Ecosystems and Environment, v.177, p.10-20, 2013. DOI: https://doi.org/10.1016/j.agee.2013.05.011. 
PONNAMPERUMA, F.N. The chemistry of submerged soils. Advances in Agronomy, v.24, p.29-96, 1972. DOI: https://doi. org/10.1016/S0065-2113(08)60633-1.

R CORE TEAM. R: A language and environment for statistical computing. Vienna: R Foundation for Statistical Computing, 2017.

SANTOS, A.B. dos; SILVA, M.A.S. da; SILVEIRA, P.M. da; CARVALHO, G.D.; STONE, L.F. Nitrogen sufficiency index for estimating nitrogen fertilizer requirement of irrigated rice. Revista Ceres, v.66, p.422-430, 2019. DOI: https://doi.org/10.1590/0034-737X201966060003.

SANTOS, H.G. dos; JACOMINE, P.K.T.; ANJOS, L.H.C. dos; OLIVEIRA, V.Á. de; LUMBRERAS, J.F.; COELHO, M.R.; ALMEIDA, J.A. de; ARAÚJO FILHO, J.C. de; OLIVEIRA, J.B. de; CUNHA, T.J.F. Sistema brasileiro de classificação de solos. 5.ed. rev. e ampl. Brasília: Embrapa, 2018. E-book.

SIGNOR, D.; CERRI, C.E.P. Nitrous oxide emissions in agricultural soils: a review. Pesquisa Agropecuária Tropical, v.43, p.322-338, 2013. DOI: https://doi.org/10.1590/S198340632013000300014.

SMITH, P.; BUSTAMANTE, M.; AHAMMAD, H.; CLARK, H.; DONG, H.; ELSIDDIG, E.A.; HABERL, H.; HARPER, R.; HOUSE, J.; JAFARI, M.; MASERA, O.; MBOW, C.; RAVINDRANATH, N.H.; RICE, C.W.; ABAD, C.R.; ROMANOVSKAYA, A.; SPERLING, F.; TUBIELLO, F.N. Agriculture, Forestry and Other Land Use (AFOLU). In: EDENHOFER, O.; PICHS-MADRUGA, R.; SOKONA, Y.; MINX, J.C.; FARAHANI, E.; KADNER, S.; SEYBOTH, K.; ADLER, A.; BAUM, I.; BRUNNER, S. EICKERMEIER, P.; KRIEMANN, B.; SAVOLAINEM, J.; SCHLÖMER, S.; STECHOW, C. VAN; ZWICKEL, T. (Ed.). Climate Change 2014: mitigation of climate change. Cambridge: Cambridge University Press, 2014. Working Group III Contribution to the Fifth Assessment Report of the Intergovernmental Panel on Climate Change. IPCC 2014. Available at: <https://www.ipcc.ch/ pdf/assessment-report/ar5/wg3/ipcc_wg3_ar5_chapter11.pdf > Accessed on: Feb. 92018.

TEDESCO, M.J.; GIANELLO, C.; BISSANI, C.A.; BOHNEN, H.; VOLKWEISS, S.J. Análise de solo, plantas e outros materiais. Porto Alegre: UFRGS, Departamento de Solos, 1995. 174p.

TIMILSINA, A.; BIZIMANA, F.; PANDEY, B.; YADAV, R.K.P.; DONG, W.; HU, C. Nitrous oxide emissions from paddies: understanding the role of rice plants. Plants, v.9, art.180, 2020. DOI: https://doi.org/10.3390/plants9020180.

VENTEREA, R.T.; PARKIN, T.B.; CARDENAS, L.; PETERSEN, S.O.; PEDERSEN, A.R. Data analysis considerations. In: DE KLEIN, C.A.M.; HARVEY, M.J. (Ed.). Nitrous oxide chamber methodology guidelines. Wellington: Ministry for Primary Industries, 2012. p.95-121.

XIA, L.; LAM, S.K.; CHEN, D.; WANG, J.; TANG, Q.; YAN, $\mathrm{X}$. Can knowledge-based $\mathrm{N}$ management produce more staple grain with lower greenhouse gas emission and reactive nitrogen pollution? A meta-analysis. Global Change Biology, v.23, p.19171925, 2017. DOI: https://doi.org/10.1111/gcb.13455.

YAN, X.; SHI, S.; DU, L.; XING, G. Pathways of $\mathrm{N}_{2} \mathrm{O}$ emission from rice paddy soil. Soil Biology \& Biochemistry, v.32, p.437-440, 2000. DOI: https://doi.org/10.1016/S0038-0717(99)00175-3.

ZOU, J.; HUANG, Y.; ZHENG, X.; WANG, Y. Quantifying direct $\mathrm{N}_{2} \mathrm{O}$ emissions in paddy fields during rice growing season in mainland China: dependence on water regime. Atmospheric Environment, v.41, p.8030-8042, 2007. DOI: https://doi.org/10.1016/j.atmosenv.2007.06.049.

ZSCHORNACK, T.; ROSA, C.M. da; CAMARGO, E.S.; REIS, C.E.S. dos; SCHOENFELD, R.; BAYER, C. Impacto de plantas de cobertura e da drenagem do solo nas emissões de $\mathrm{CH}_{4}$ e $\mathrm{N}_{2} \mathrm{O}$ sob cultivo de arroz irrigado. Pesquisa Agropecuária Brasileira, v.51, p.1163-1171, 2016. DOI: https://doi.org/10.1590/s0100$204 \times 2016000900016$. 